\title{
Article \\ Long-Lasting Growth Hormone Regulated by the Ubiquitin-Proteasome System
}

\author{
Myung-Sun Kim ${ }^{1,+}$, Kyunggon Kim ${ }^{2,3,4,5,+} \mathbb{D}$, Su Kyung Oh ${ }^{1}$, Gidae Lee ${ }^{1}$, Jin-Ock Kim ${ }^{6}$, Lan Li ${ }^{6,7}$, \\ Jung-Hyun Park ${ }^{6}$ and Kwang-Hyun Baek ${ }^{6, *(D)}$
}

1 UbiProtein Corp., Seongnam-si 13493, Korea; lg-kms@hanmail.net (M.-S.K.); pomnagea@hanmail.net (S.K.O.); gdlee1129@gmail.com (G.L.)

2 Asan Institute for Life Sciences, Asan Medical Center, Seoul 05505, Korea; kimkyunggon@gmail.com

3 Department of Convergence Medicine, University of Ulsan College of Medicine, Seoul 05505, Korea

4 Clinical Proteomics Core Laboratory, Convergence Medicine Research Center, Asan Medical Center, Seoul 05505, Korea

5 Bio-Medical Institute of Technology, Asan Medical Center, Seoul 05505, Korea

6 Department of Biomedical Science, CHA University, Seongnam-si 13488, Korea; kjo8909@gmail.com (J.-O.K.); dreamerlanlan@gmail.com (L.L.); jhpark6237@nate.com (J.-H.P.)

7 School of Basic Medical Sciences, North China University of Sciences and Technology, Tangshan 063210, China

* Correspondence: baek@cha.ac.kr; Tel.: +82-31-881-7134

+ Co-first author.

check for updates

Citation: Kim, M.-S.; Kim, K.; Oh, S.K.; Lee, G.; Kim, J.-O.; Li, L.; Park, J.-H.; Baek, K.-H. Long-Lasting Growth Hormone Regulated by the Ubiquitin-Proteasome System. Int. J. Mol. Sci. 2021, 22, 6268. https:// doi.org/10.3390/ijms22126268

Academic Editor: Atsushi Matsuzawa

Received: 7 April 2021

Accepted: 7 June 2021

Published: 10 June 2021

Publisher's Note: MDPI stays neutral with regard to jurisdictional claims in published maps and institutional affiliations.

Copyright: (c) 2021 by the authors. Licensee MDPI, Basel, Switzerland. This article is an open access article distributed under the terms and conditions of the Creative Commons Attribution (CC BY) license (https:// creativecommons.org/licenses/by/ $4.0 /)$.

\begin{abstract}
To increase the half-life of growth hormones, we proposed its long-lasting regulation through the ubiquitin-proteasome system (UPS). We identified lysine residues (K67, K141, and K166) that are involved in the ubiquitination of human growth hormone (hGH) using ubiquitination site prediction programs to validate the ubiquitination sites, and then substituted these lysine residues with arginine residues. We identified the most effective substituent (K141R) to prevent ubiquitination and named it AUT-hGH. hGH was expressed and purified in the form of hGH-His, and ubiquitination was first verified at sites containing K141 in the blood stream. Through the study, we propose that AUT-hGH with an increased half-life could be used as a long-lasting hGH in the blood stream.
\end{abstract}

Keywords: anti-ubiquitination technology; half-life; hGH; ubiquitination

\section{Introduction}

The human growth hormone (hGH) is synthesized as $22 \mathrm{kDa}$ polypeptide and stored in the anterior pituitary gland by somatotroph cells [1]. It acts either directly or indirectly on various tissues and physiological systems such as longitudinal bone, skeletal muscle, liver, total body nitrogen balance, and so on [2]. A recombinant hGH (rhGH) is produced as a 191-amino acid protein that acts as an endocrine hormone, stimulating growth, cell reproduction, and regeneration [3]. This rhGH has been used clinically since 1985 for the treatment of children's growth disorders caused by a growth hormone deficiency, chronic renal failure, Turner's syndrome, and adult growth hormone deficiency [4]. Some of the leading global human growth hormones available commercially are Biotropin (Lifetech Labs, Hong Kong), Genotropin (Pfizer Inc., New York, NY, USA), Norditropin (Norvo Nordisk Inc., Plainsboro, NJ, USA), Humatrope (Eli Lilly and Company, Indianapolis, IN, USA), Saizen (Merck Serono, Darmstadt, Germany), Hypertropin (Neogenica bioscience Ltd., China), Ansomone (AnkeBio Co., Anhui, China), Serostim (EMD Serono Inc., Rockland, MA, USA), Jintropin (GeneScience Pharmaceuticals Co., Jilin, China) and Hygetropin (Hygene BioPharm Co., China). However, the rhGH therapy should be performed daily or three times a week, because these drugs have a short half-life in the blood circulation due to low uptake by proteolytic system enzymes. The therapy causes several problems including weak compatibility, renal toxicity, and an increase in treatment cost for the patient [4]. 
Therefore, a lot of studies have been conducted in recent years with the aim of increasing the half-life of the drugs. For a sustained release of rhGH, a lot of formulations have been used. Examples of approaches include coating of a monomolecular layer of positively charged poly arginine with hGH for crystalline formulation [5], protein encapsulation into polymeric microspheres [6,7], injectable hydrogels [8-10], and degradable implants [11,12]. Moreover, various protein fusion techniques including PEGylation (where PEG stands for polyethylene glycol), binding with albumin or antigen-binding fragment (Fab), and fusion with other proteins, have recently been attempted to develop sustained growth hormones [13]. Representative products using these techniques are GX-H9 [14,15], MOD4023 [16,17] LAPSrhGH [13] AG-B1512 [13], Somapacitan [18-20], Jintrolong [21,22], and so on. However, these methods cannot be used for the production of some protein pharmaceuticals due to the large size of the fusion protein, which may result in decreased productivity and instability. In this study, the mechanism of protein degradation that occurs when hGH circulates in the body is evaluated.

In eukaryotic cells, proteins and peptides degrade in two ways, lysosomal or through ubiquitin-proteasome system (UPS) [23]. About $80 \%$ of proteins degrade through UPS, which regulates the degradation of most cellular proteins in eukaryotes and presides over protein turnover and homeostasis in vivo [23]. The ubiquitin, a key protein of UPS, is a small protein consisting of 76 highly conserved amino acids in all eukaryotic cells [23]. For the selective degradation of a protein in eukaryotic cells, E1 (ubiquitin-activating), E2 (ubiquitin-conjugating) and E3 (ubiquitin-ligase) enzymes act in continuation to promote the ubiquitination of the target proteins. The ubiquitin-tagged proteins are then decomposed by the $26 \mathrm{~S}$ proteasome of ATP-dependent protein degradation complex $[23,24]$. Recently, it has been reported that extracellular ubiquitin is found at nanomolar concentrations in human plasma and serum [25]. Plasma ubiquitin levels are elevated during hairy cell leukemia (HCL), allergy, autoimmune infections, and other disorders [26]. Moreover, extracellular ubiquitin plays the role of an immune modulator affecting $\mathrm{T}$ and $\mathrm{B}$ lymphocytes [27] and is involved in the regulation of the immune system [25]. Extracellular ubiquitination regulates the initiation, propagation, and termination of immune responses such as intracellular ubiquitination [25].

In this study, we confirmed the ubiquitination of hGH in blood for the first time and constructed an effective substituent (K141R) to prevent the ubiquitination of hGH via an in vitro assay. This suggests that AUT-hGH with an increased half-life might be a long-lasting hGH in the blood stream.

\section{Results}

\section{1. hGH Mutants Are Less Ubiquitinated}

For these experiments, we used the hGH precursor form. The numbering of mutations was also based on the precursor form (Supplementary Figure S1). To investigate whether hGH is ubiquitinated in the cells, we performed a ubiquitination assay (Figure 1A). In overexpressed cells of hGH with the Flag-tag, poly ubiquitin chain formation was observed (Figure 1A, lane 2), which increased after treatment with MG132 (proteasome inhibitor, $5 \mu \mathrm{g} / \mathrm{mL}$ ) for $6 \mathrm{~h}$ (Figure 1A, lane 3). These smear bands indicate poly ubiquitin chain formation, and more intense bands indicate increased poly ubiquitin chain formation (Figure 1A, lane 3). Moreover, to find a site that can effectively prevent the ubiquitination of hGH, its mutant forms were constructed (Supplementary Table S1), and a ubiquitination assay was performed (Figure 1B). It can be observed that the smear bands that indicate poly ubiquitin chain formation are less intense in hGH (K67R), hGH (K141R) and hGH (K166R) mutants as compared to the wild-type (WT) (Figure 1B, lanes 3-5). These results suggest that a smaller amount of ubiquitin was detected because the ubiquitin did not bind to the mutant hGH. These results indicate that ubiquitin first binds to an hGH, and then a poly ubiquitin chain is formed, and finally the hGH is degraded by the UPS. 


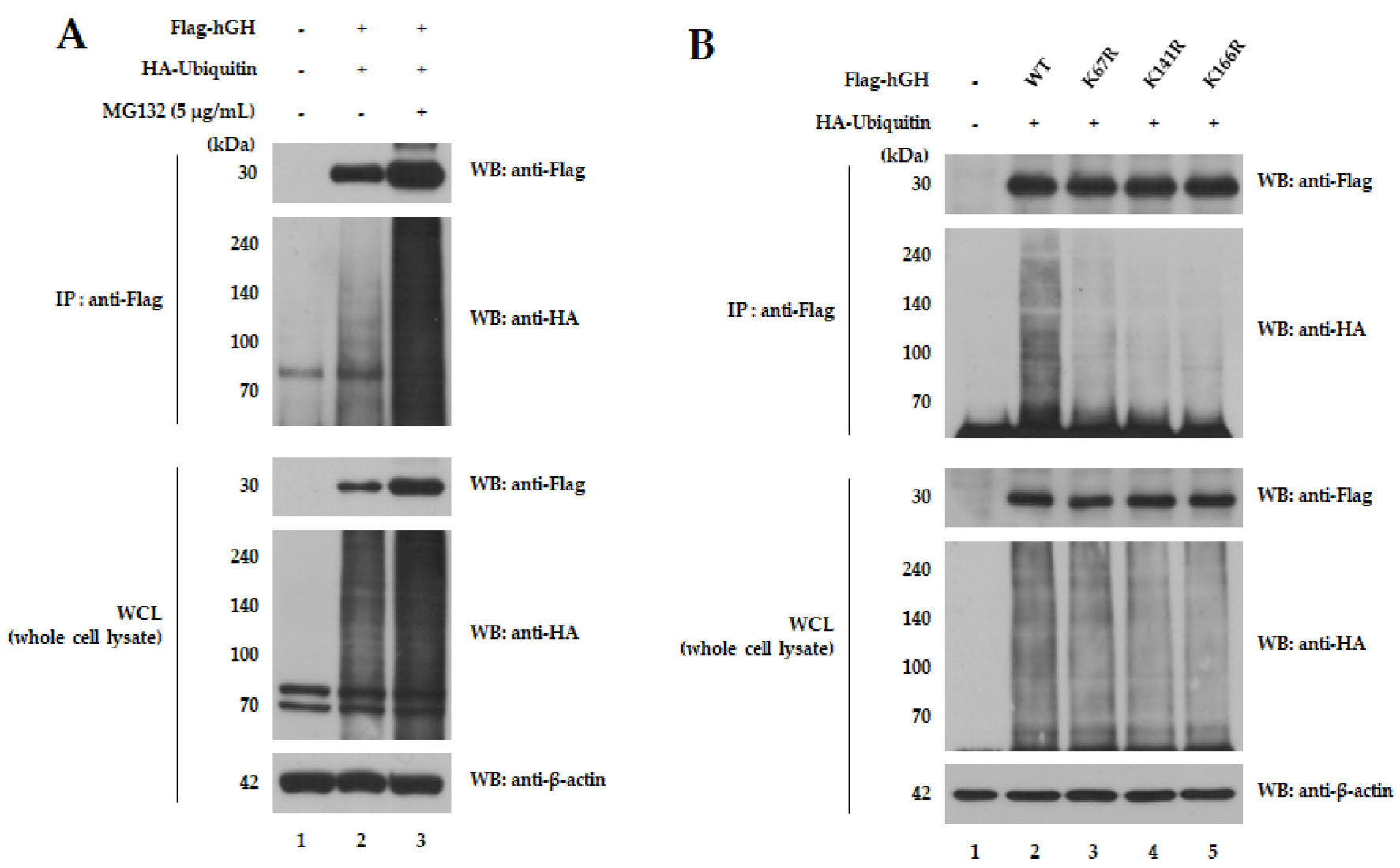

Figure 1. The ubiquitination of hGH and its mutants in cells. (A) Ubiquitination of hGH. 293T cells were transfected with Flag-hGH and HA-ubiquitin together. Ubiquitination of hGH was confirmed by co-immunoprecipitation with an anti-Flag antibody and the counter blot was detected by an anti-HA antibody. hGH forms a poly ubiquitin chain and thus increases it after treatment with MG132 (proteasome inhibitor, $5 \mu \mathrm{g} / \mathrm{mL}$ ) for $6 \mathrm{~h}$. (B) Ubiquitination of hGH mutants. The 293T cells were transfected with each Flag-hGH (K67R), hGH (K141R) and hGH (K166R) and HA-ubiquitin together. Ubiquitination level was checked by co-immunoprecipitation with an anti-Flag antibody and immunoblotting with an anti-HA antibody. Mutants of hGH create less poly ubiquitin chain formation compared to the WT.

\section{2. $h G H$ (K141R) Extends Its Half-Life}

To verify whether hGH mutants extend their half-life, the hGH mutants K67R, K141R, and K166R were used (Supplementary Table S1). To confirm the half-life of every protein, we checked the bands that indicate hGH at $0,1,2,4$ and $8 \mathrm{~h}$ after the treatment with protein synthesis inhibitor and cycloheximide (CHX) $(100 \mu \mathrm{g} / \mathrm{mL})$ (Figure 2A). Hence, the half-life of hGH (K141R) was prolonged to $8 \mathrm{~h}$ or more, while the half-life of hGH (WT) was less than $2 \mathrm{~h}$ (Figure 2A). The intensity of the band was relatively quantified and shown as a graph (Figure 2B). In contrast, the hGH expression levels increased in a time-dependent manner, because proteasome inhibition occurred with the treatment of MG132 (Figure 2C). These results show that not all lysines that block ubiquitination increase the half-life. Therefore, this indicates that the K141 site of hGH plays a key role in extending its half-life. Subsequently, hGH (K141R) that increased the half-life of hGH was named AUT-hGH. 


\section{A}
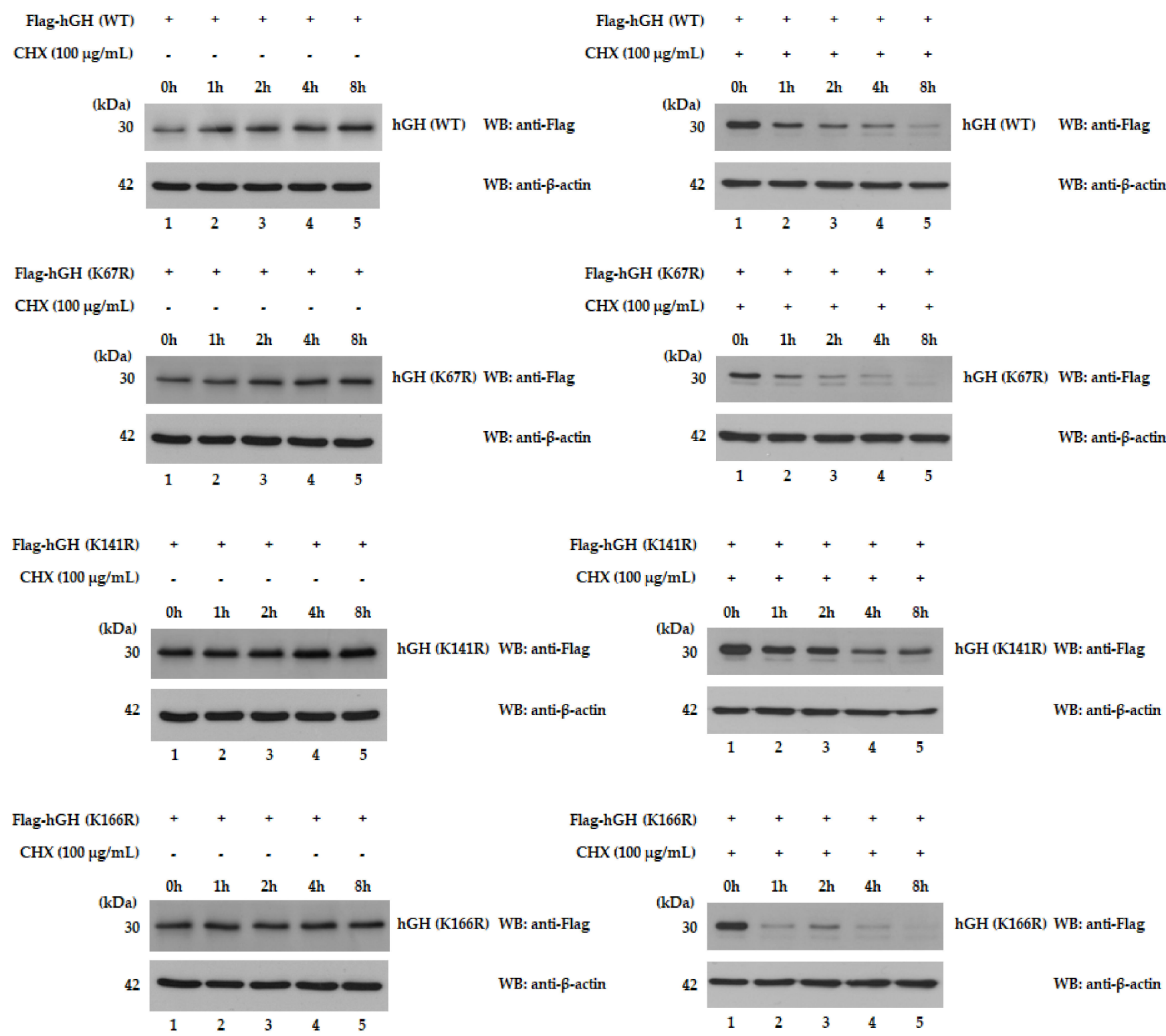

B
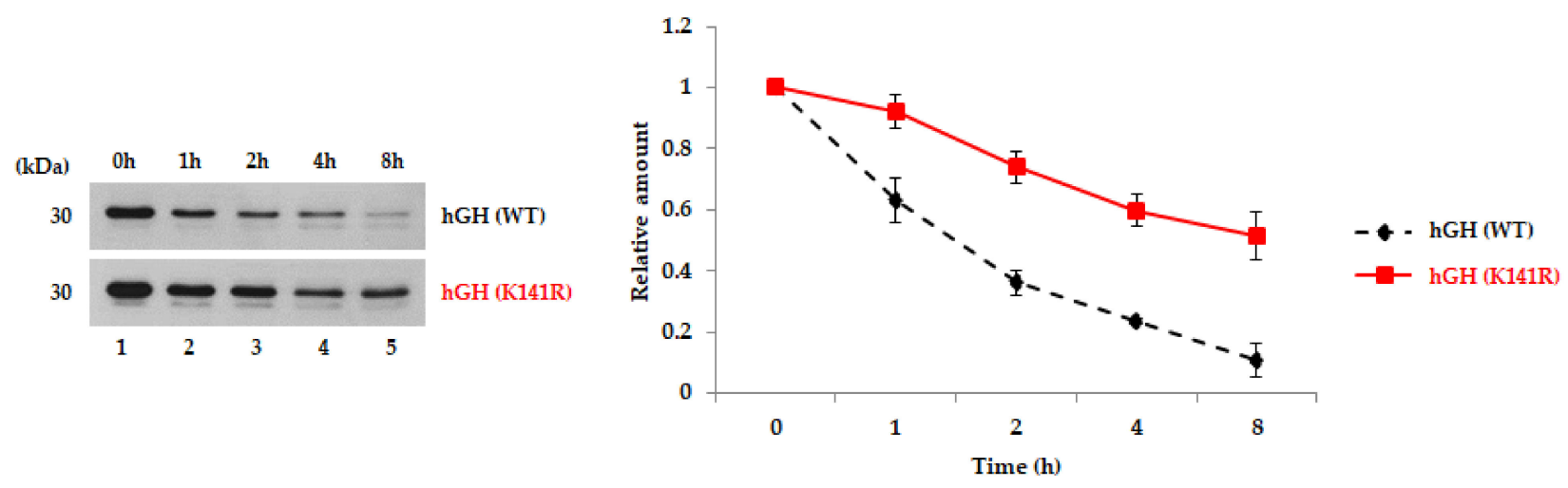

Figure 2. Cont. 


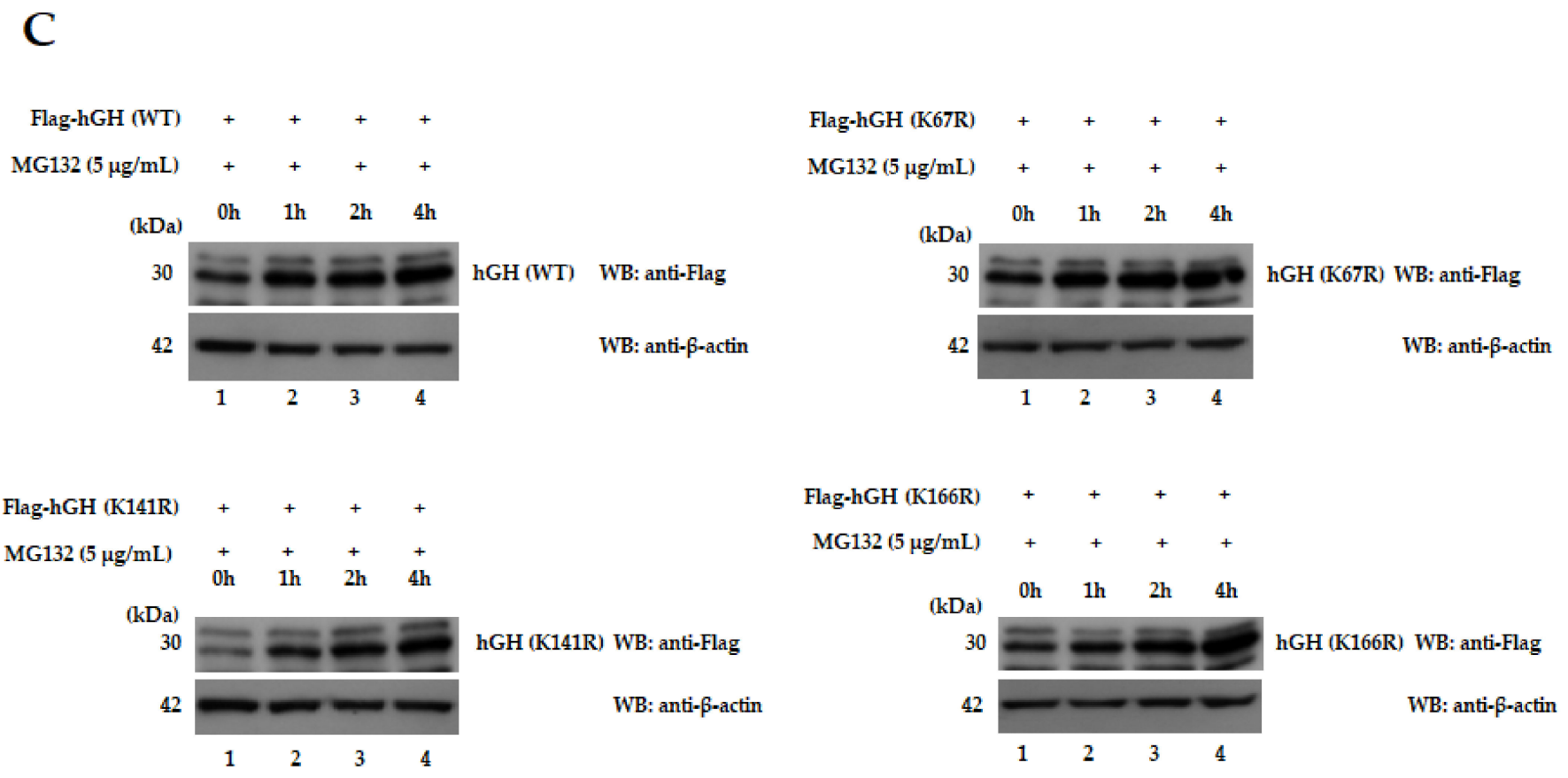

Figure 2. Half-life test of hGH and its mutants in cells. (A) hGH (K141R) increased the half-life. 293T cells were individually transfected with Flag-hGH (K67R), hGH (K141R) and hGH (K166R). At 24 h following transfection, CHX was treated at a concentration of $100 \mu \mathrm{g} / \mathrm{mL}$ for $0,1,2,4$, and $8 \mathrm{~h}$, and then cell lysates were prepared. The presence of hGH protein was detected using an anti-Flag antibody. The half-life of hGH (K141R) was prolonged to $8 \mathrm{~h}$ or more, while the half-life of hGH (WT) was less than $2 \mathrm{~h}$. (B) The intensity of the band between hGH (WT) and hGH (K141R) was relatively quantified and is shown as a graph. (C) Proteasome inhibition of hGH increased in a time-dependent manner with the treatment of MG132.

\subsection{AUT- $h \mathrm{GH}$ and $h \mathrm{GH}$ Were Purified in Their Untagged Form}

Protein expression at low temperatures often significantly improves the solubility of recombinant proteins [28-30]. Therefore, we tried several conditions for the culture of hGH and production of hGH and AUT-hGH. In this study, recombinant AUT-hGH and hGH were induced at $20^{\circ} \mathrm{C}$ and the amount of soluble hGH and AUT-hGH increased without tagging (Figure 3). The results show that their molecular weights were approximately $22.26 \mathrm{kDa}$ (hGH (WT); expected: $22.246 \mathrm{kDa}$ ) and $22.28 \mathrm{kDa}$ (AUT-hGH; expected: $22.246 \mathrm{kDa}$ ). We observed a major band, indicating high purity obtained by silver staining (Figure 3C). 
A

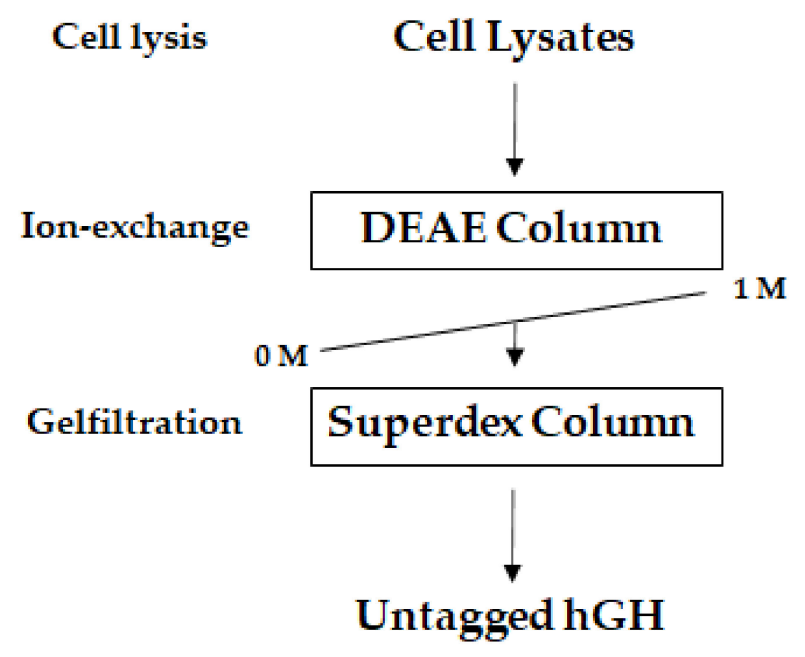

B
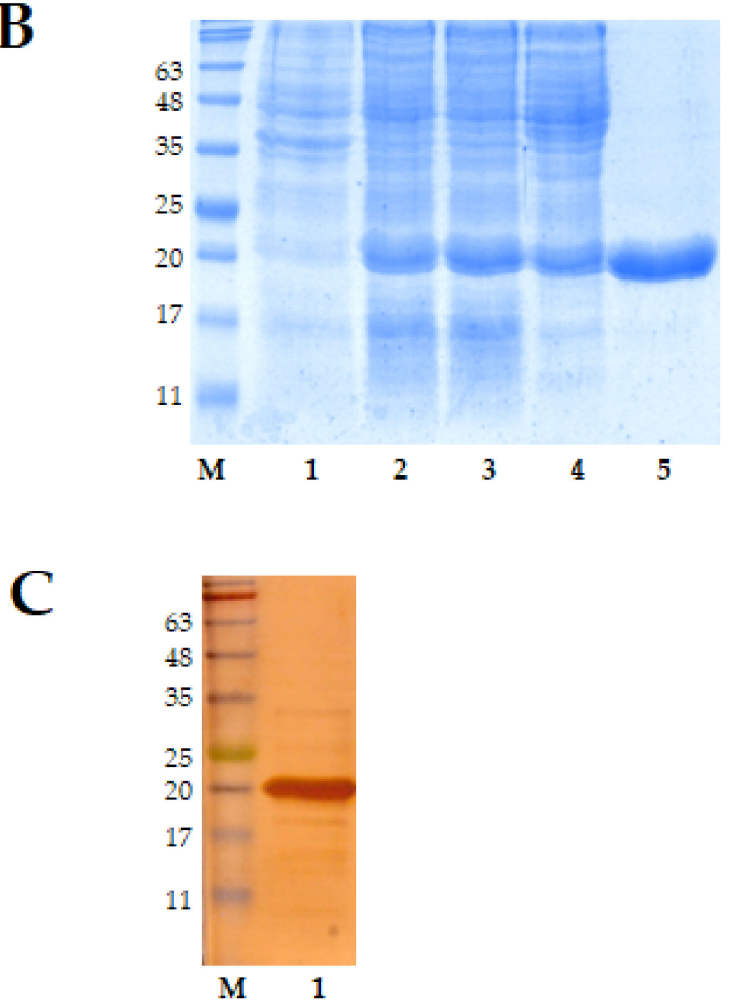

Figure 3. Purification of recombinant AUT-hGH. (A) Scheme of untagged AUT-hGH purification from E. coli. The purification process was followed by cell lysis, ion-exchange, and gel filtration. (B) Purification of untagged AUT-hGH. At each step, elutions from each column were separated by $15 \%$ sodium dodecyl sulfate-polyacrylamide (SDS-PAGE) gel and analyzed by Coomassie blue staining. $\mathrm{M}$ indicates molecular weight marker; lane 1 indicates total protein before isopropyl $\beta$-D-1-thiogalactopyranoside (IPTG) induction; lane 2 shows the soluble fraction after IPTG induction and cell lysis; lane 3 shows soluble fraction before passing the diethylaminoethyl (DEAE) column for ion-exchange; lane 4 shows soluble fraction after passing DEAE column for ion-exchange; lane 5 shows purified untagged AUT-hGH after passing Superdex column for gel filtration. hGH was also purified by the same process. (C) Silver staining of $6 \mu \mathrm{g}$ of purified untagged AUT-hGH. M, molecular weight marker; lane 1, untagged AUT-hGH.

\subsection{Structure and Biological Activity of $h G H$ and AUT-hGH}

A structural comparison of hGH and AUT-hGH was performed to detect whether there is any difference between the WT hGH and AUT-hGH (Figure 4A). Root mean square deviation (RMSD) is commonly used to measure the similarity between two superimposed atomic coordinates [31]. Lysine 141 is in a stable alpha-helix motif and substitution to arginine was simulated using in silico method. There is no structural hindrance and no change in Ramachandran Plot after substitution using WinCoot (ver. 0.9.4.1) [32] and Calphacarbon RMSD between the two structures was $0.0044 \AA$, indicating that the substitution of lysine to arginine in 141 residue does not vary the secondary structure.

To determine whether the purified hGH and AUT-hGH were biologically active, we verified the signal transduction in the NIH3T3 cells. It has been reported that the growth hormone controls the transcription of STAT protein [33], and mediators in GH signaling pathway include STATs and PI3K-AKT [34]. In this study, we treated rhGH and AUT-hGH, and used commercial hGH (Saizen) as a positive control. NIH3T3 cells were starved for $24 \mathrm{~h}$ and then treated with hGH, AUT-hGH, and commercial hGH at a concentration of $100 \mathrm{ng} / \mathrm{mL}$. After 2 days of treatment, their signal transduction was evaluated by Western blot analysis (Figure 4B). AUT-hGH showed intense phospho-STAT3, and phospho-AKT in NIH3T3 cells similar to hGH and commercial hGH. Hence, AUT-hGH maintains biological activity in NIH3T3 cells. 
A

hGH
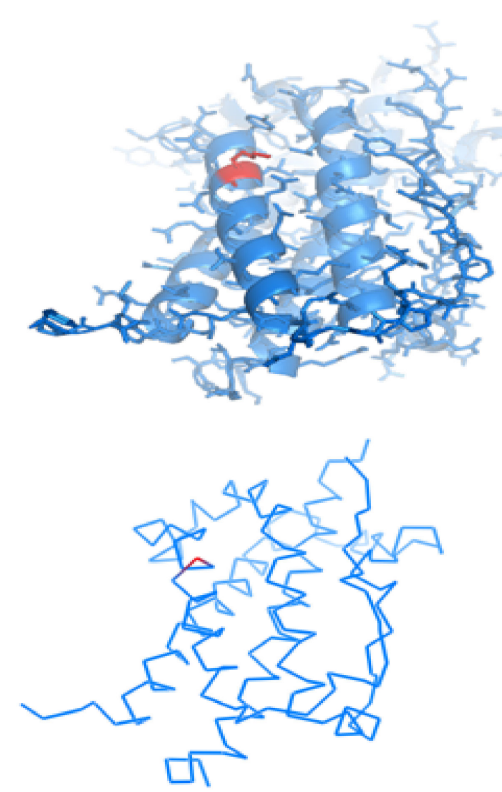

AUT-hGH

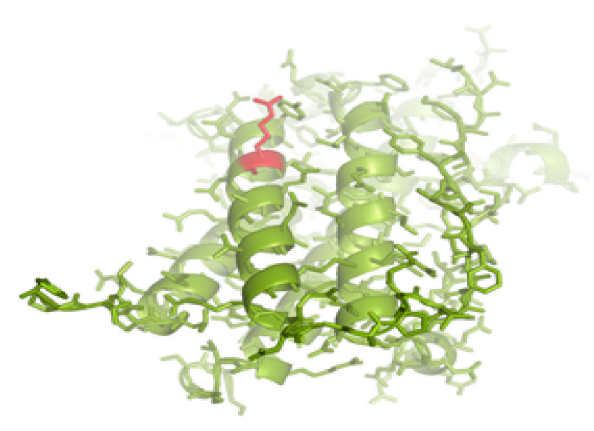

Core RMSD : $0.0044 \AA$

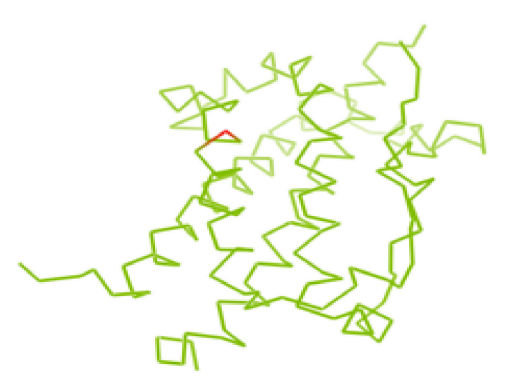

B

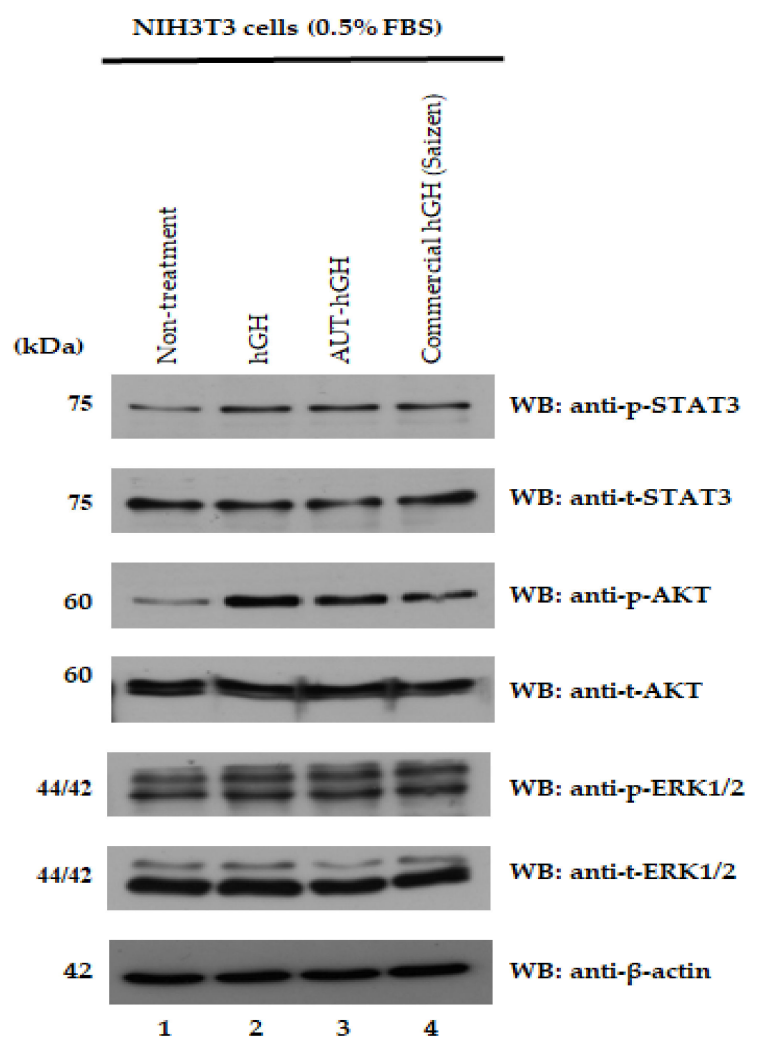

Figure 4. Comparison of structure and biological activity between hGH and AUT-hGH. (A) Structural similarity between hGH and AUT-hGH. The core RMSD score of $0.0044 \AA$ shows that AUT-hGH has a structure similar to hGH. Red positions indicate K141 and R141 in hGH and AUT-hGH, respectively. (B) Signal transduction of purified AUT-hGH in NIH3T3 cells. Starved NIH3T3 cells were treated with $100 \mathrm{ng} / \mathrm{mL}$ concentrations of hGH, AUT-hGH, and commercial hGH for $24 \mathrm{~h}$. After 2 days of treatment, phospho-STAT3, phospho-AKT, and phospho-ERK 1/2 proteins were detected using an anti-p-STAT3, anti-p-AKT, and anti-p-ERK1/2 antibodies. The counter blots were detected by antibodies against proper total forms and $\beta$-actin. AUT-hGH induced phospho-STAT3 and phospho-AKT in NIH3T3 cells like hGH and commercial hGH. 


\section{5. hGH Ubiquitination in the Blood Stream}

We checked whether hGH is ubiquitinated in blood, because it has been reported that that extracellular ubiquitin is found at nanomolar concentrations in human plasma and serum [25-27]. To confirm the ubiquitination of hGH in blood, purified hGH-His was incubated for $1 \mathrm{~h}$ in a mouse whole blood sample. Subsequently, a pull-down assay was performed on hGH-His using nickel nitrilotriacetic acid (Ni-NTA) beads, and mass spectrometry (MS) and Western blot analysis were performed to identify ubiquitination (Figure 5 and Supplementary Table S2). Hypothetically, precipitated hGH-His from mouse blood is exposed to the ubiquitination system of mouse blood and a lysine residue is obtained, which is modified to Gly Gly at epsilon-amine. This is a significant modification of ubiquitination. The spectrum of hGH indicates the clear isopeptide of glycine with a K141 residue (Figure 5A). Furthermore, Western blot analysis using an anti-ubiquitin antibody showed that hGH undergoes polyubiquitination in the blood stream, and MG132 increases the band smear (Figure $5 \mathrm{~B}$ ). This is the first report that hGH is polyubiquitinated in the blood stream. It was confirmed again that if the lysine at 141 of hGH was substituted with arginine, the binding of ubiquitin with hGH would be prevented.

A
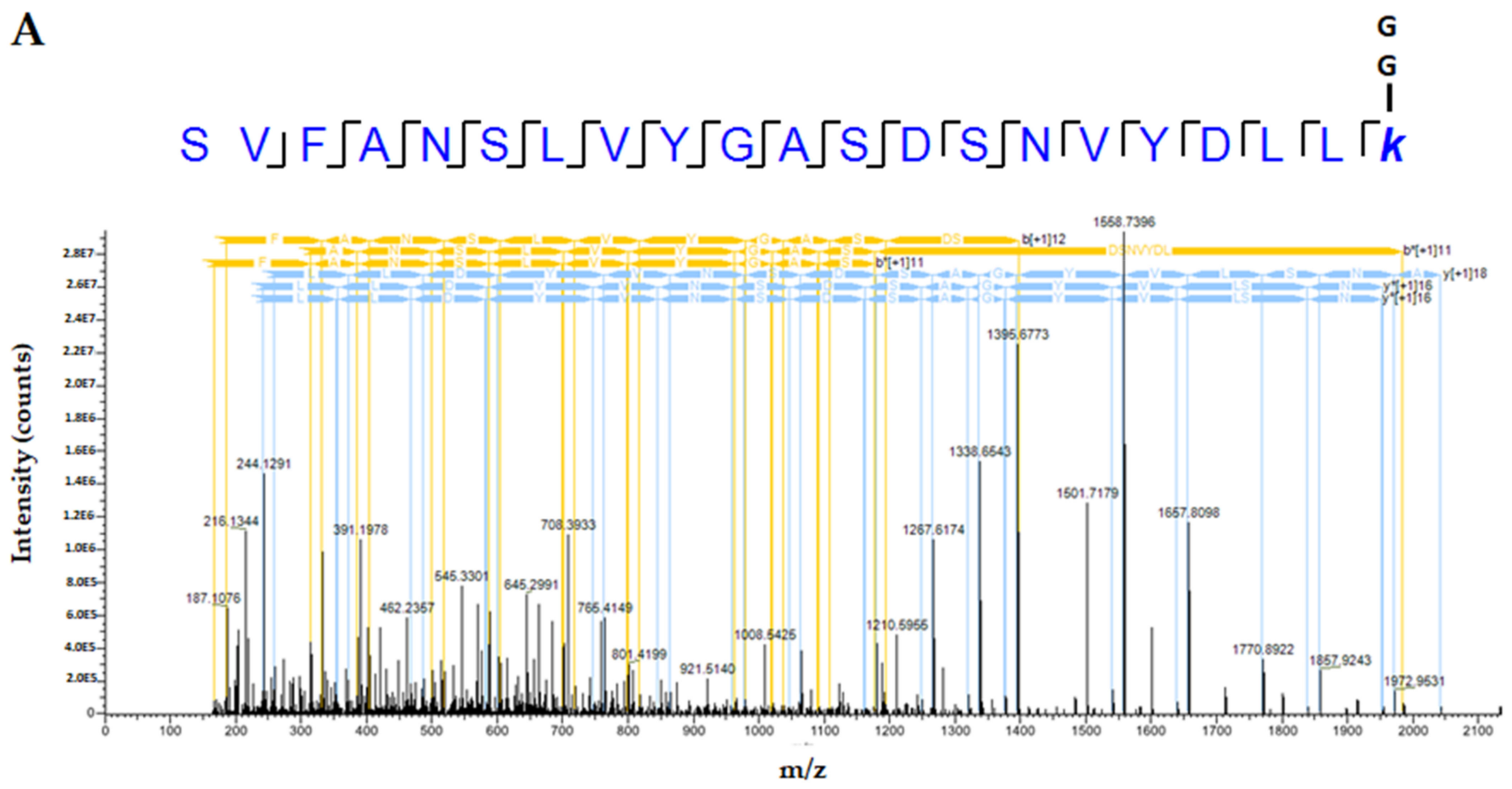

- Charge: +2

- Monoisotopic m/z: 1,188.59081 Da (+1.28 mmu/+1.08 ppm)

- $\mathrm{MH}+: 2,376.17435 \mathrm{Da}$

- $\quad$ RT: $179.3751 \mathrm{~min}$

- XCorr: 5.25

- Percolator q-Value: $0.0 \mathrm{e} 0$

- Percolator PEP: 1.2e-6

- Fragment Match Tolerance: $0.02 \mathrm{Da}$

Figure 5. Cont. 


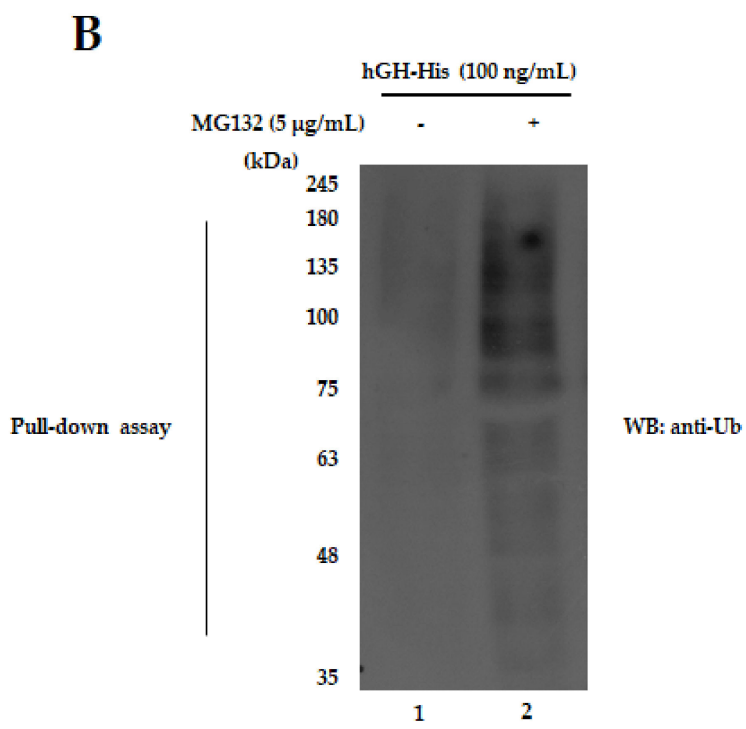

Figure 5. (A) MS analysis of ubiquitination for hGH in the blood stream. The hGH at K141 residue is modified to be Gly Gly at epsilon-amine, which is a significant modification of ubiquitination. (B) Polyubiquitination of hGH in the blood stream. hGH-His was incubated for $1 \mathrm{~h}$ at $37^{\circ} \mathrm{C}$ in blood. Lane 1 indicates $100 \mathrm{ng} / \mathrm{mL}$ hGH-His without MG132; lane 2 shows $100 \mathrm{ng} / \mathrm{mL}$ hGH-His with MG132.

\subsection{Increase in AUT-hGH Half-Life in the Blood Stream}

The half-life of AUT-hGH increases in the blood stream. In the study, hGH, AUT-hGH, and commercial hGH (Saizen) were subcutaneously administrated to male Sprague Dawley (SD) rats. The blood was collected at $0,1,2,4,8,12,16,24,30$, and $48 \mathrm{~h}$ after administration, and the plasma was separated. Using the plasma, we measured the hGH protein in the blood stream using an enzyme-linked immunosorbent assay (ELISA) (Figure 6). The graph shows the pharmacokinetic graphs of the hGH, AUT-hGH, and the Saizen (Figure 6). The plasma half-life of the AUT-hGH increases approximately 1.5-fold compared to hGH, and 1.33-fold compared to the Saizen.

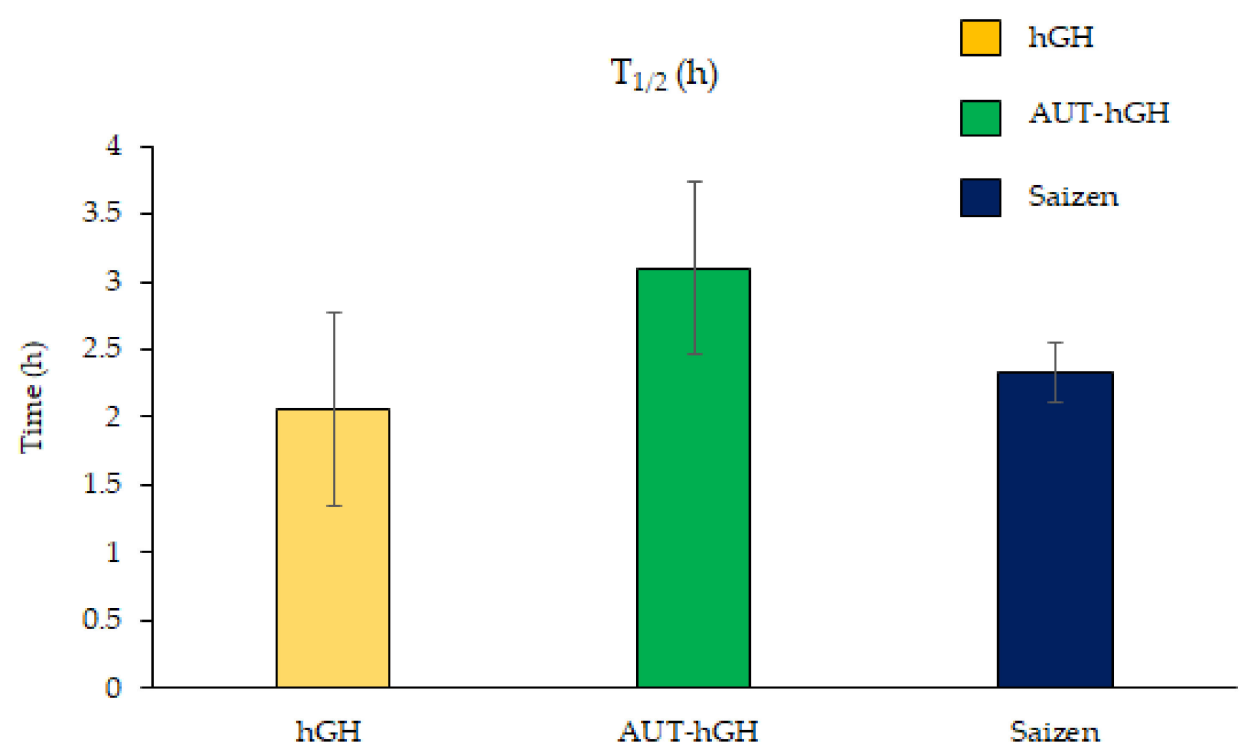

Figure 6. The pharmacokinetic graphs of the hGH, AUT-hGH, and the Saizen. The half-life of the hGH, AUT-hGH, and the Saizen was analyzed. The half-life of AUT-hGH seems to be the longest. 


\subsection{Maintaining the Efficacy of AUT- $h \mathrm{GH}$}

To check the efficacy of AUT-hGH, rats with their pituitary gland removed at 4 weeks of age were administered hGH and AUT-hGH on a daily basis, and in intervals of 3 days and 7 days, repeatedly. Normal mice were used as a positive control, and mice that were not treated with hGH were used as a negative control. To measure the tibia length, we checked that the distance between growth plate and the band formed by tetracycline (Figure 7). As a result, the negative control group was significantly decreased compared to the normal control group (Figure 7, G1 and G2). In SD rats which were daily administrated with hGH and AUT-hGH, the bone growth rate significantly increased compared to the negative control group (Figure 7, G3 and G4). In contrast, in SD rats which were administrated with hGH and AUT-hGH at intervals of 3 days and 7 days, hGH and AUT-hGH maintained a similar growth promoting effect (Figure 7, G5-G8).
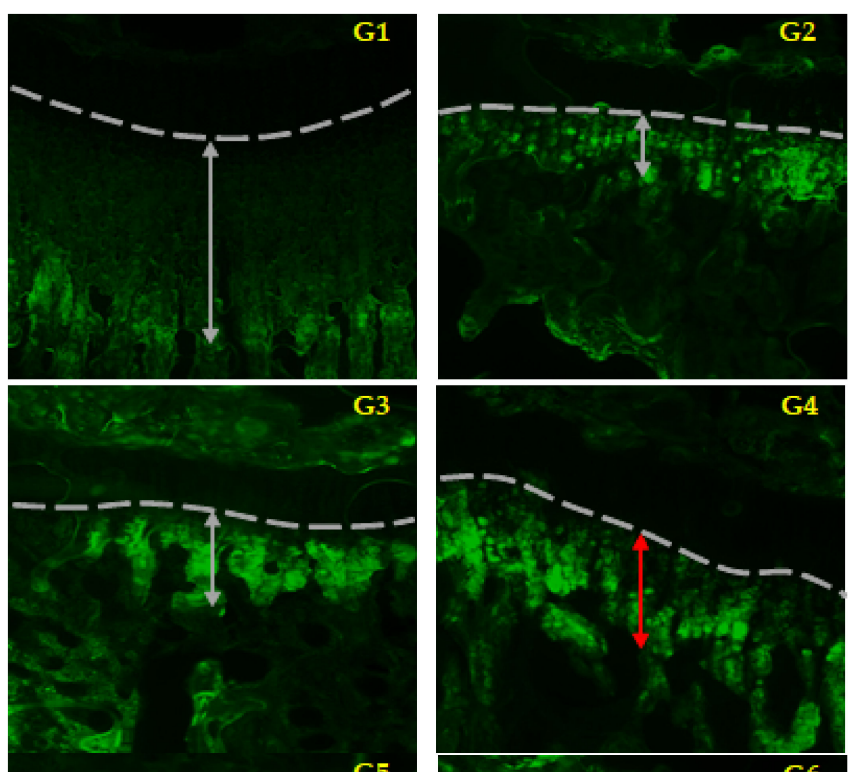

G5
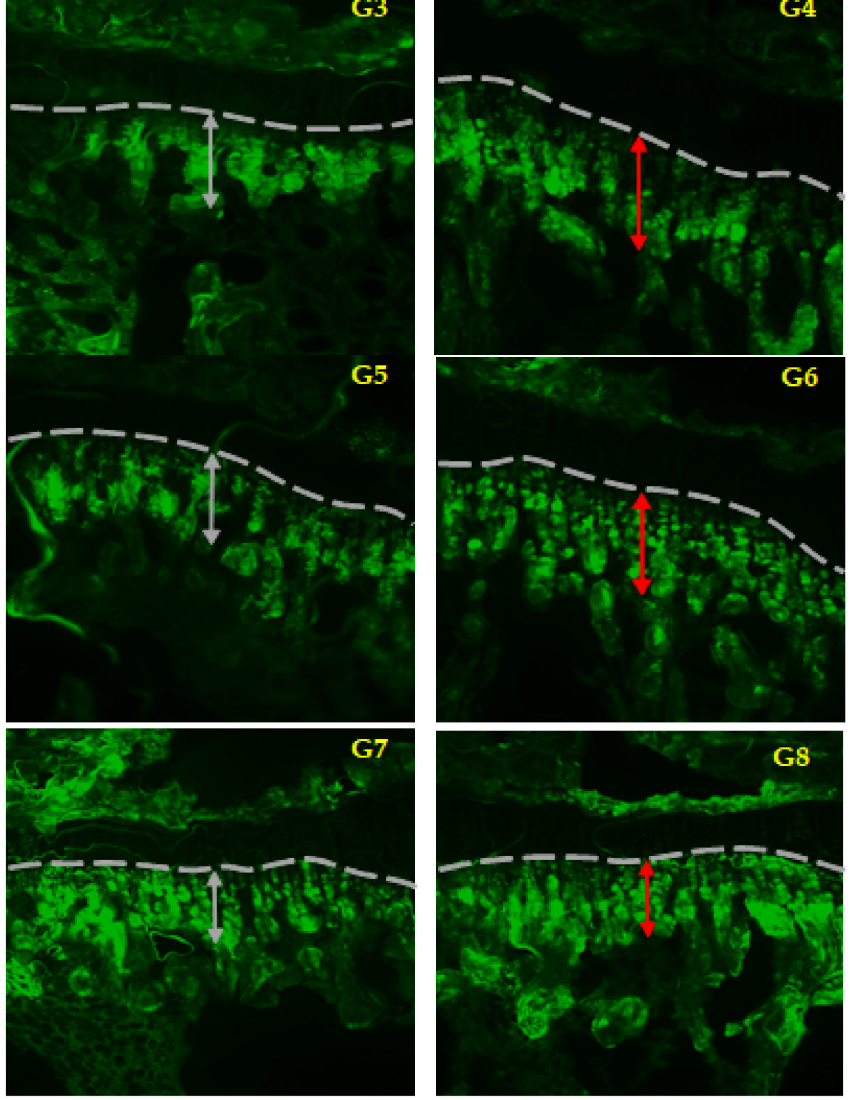

Figure 7. Maintaining the efficacy of AUT-hGH. The white and red arrows indicate the distance between the growth plate and the band formed by tetracycline. G1 indicates a normal rat, and G2 is a rat with its pituitary gland removed. G3 and G4 indicate rats which were daily administered, G5 and G6 are rats which were administered at intervals of 3 days, and G7 and G8 are those administered at intervals of 7 days. G3, G5, and G7 were administrated hGH, and G4, G6, and G8 were administrated AUT-hGH. 


\section{Discussion}

Because growth hormone is received by subcutaneous injection every day, patients require convenience. Therefore, diverse methods for the development of long-lasting hGH have been suggested. As a slow-release product, Genentech first launched Neutrofind Depot., and LG Life Science released Diclase in 2007 [13]. However, the sustained-release therapeutic agent causes an unwanted immune response in the human body, causes pain due to the use of a thick syringe, and is not economically viable due to a low production yield. Neutropin Depot was withdrawn from the market because it was less effective than the first generation. Additionally, fused sugar chain engineering with polyethylene glycol as a polymer is used to increase endurance. However, highly concentrated PEG, used as a protein stabilizer, has been reported to be unsafe. SonoVue (a commercial contrast agent containing PEG) may cause anaphylactic shock, and polysorbate 80 (PEG-containing polymer) may cause urticarial shock. Anti-PEG also increases drug abstinence, poses a risk of subsequent infusion reactions, and increases tissue fears in animals treated with PEGylated protein [35-41]. Fusion with other proteins enables the development of longlasting $\mathrm{hGH}$, which is used as anti-human serum albumin Fab antibody, immunoglobulin Fc portion of IgD and IgG4, and carboxyl-terminal peptide (CTP) of hCG $\beta$-subunit [13]. However, these methods have not been used as a universal half-life increasing method due to various reasons such as lack of economic efficiency at a low production yield, occurrence immune reactions with long-term use, and the toxicity of chemicals used in the binding process. Therefore, these methods are currently being studied to find solutions for these limitations and problems.

To find solutions to address these limitations and problems, we explored a mechanism of protein degradation that naturally occurs when hGH circulates in the body. Here, we confirmed that hGH is ubiquitinated in the blood stream, and $\mathrm{K} 141$ of hGH plays a role in the ubiquitination. Therefore, the AUT-hGH that changed the K141 to R141 caused a reduction in ubiquitination and an increase in half-life. To confirm the polyubiquitination of hGH in the blood stream (Figure 5B), we first considered the presence of ATP, E1 (ubiquitin-activating), E2 (ubiquitin-conjugating), and E3 (ubiquitin-ligase) enzymes in the blood stream. ATP is present in human plasma [26]. Recently, according to the human plasma proteome database that summarizes the results of analysis on human blood proteins (http:/ / www.plasmaproteomedatabase.org/, accessed on 10 May 2021), proteasome and ubiquitin-related enzymes of units of $\mathrm{ng} / \mathrm{mL}$ are present in plasma. Therefore, it is meaningful to state that the polyubiquitination of hGH occurs in blood.

Moreover, because we only substituted one amino acid, there was little change in the tertiary structure of the protein, and no change in protein size. Hence, patients do not experience pain, as in the case of fusion with other proteins. AUT-hGH did not maximize its half-life in the body; this limitation can be overcome by using existing technologies. Future developments in AUT technology will introduce these benefits. For example, we plan to combine AUT technology with the existing long-lasting technology, which has several limitations and problems, and suggest AUT-hGH-PEG, AUT-hGH-CTP, and so on. These trials may enable the development of more effective long-lasting protein-based drugs.

\section{Materials and Methods}

\section{1. $h \mathrm{GH}$ and Its Mutants for Expression}

\subsubsection{Preparation of hGH in Mammalian Cells}

The $h G H$ DNA amplified by a polymerase chain reaction (PCR) was treated with Eco $\mathrm{RI}$, and then ligated to pCS4-Flag vector [42], previously digested with the same enzyme. The PCR conditions are as follows: Step 1: at $94{ }^{\circ} \mathrm{C}$ for $3 \mathrm{~min}$ (1 cycle); Step 2: at $94{ }^{\circ} \mathrm{C}$ for $30 \mathrm{~s}$; at $60^{\circ} \mathrm{C}$ for $30 \mathrm{~s}$; at $72{ }^{\circ} \mathrm{C}$ for $30 \mathrm{~s}\left(25\right.$ cycles); and Step 3: at $72{ }^{\circ} \mathrm{C}$ for $10 \mathrm{~min}$ ( 1 cycle), and then held at $4{ }^{\circ} \mathrm{C}$. 


\subsubsection{Isolation and Substitution of Lysine (K) Residue}

To determine lysine residues involved in the ubiquitination process, we used prediction of ubiquitination sites with Bayesian Discriminant Method (http:/ /bdmpub.biocuckoo. org / prediction. php, accessed on 10 May 2021) with "high sensitivity" as a performance selection.

For hGH mutants, lysine residues were replaced with arginine (R) using site-directed mutagenesis. The following primer sets were used for PCR to produce the mutated plasmid DNAs. For hGH K67R, fwd 5'-CCAAAGGAACAGAGGTATTCATTC-3', rev 5'-CAG GAATGAATACCTCTGTTCCTT-3' ; for hGH K141R, fwd $5^{\prime}$-GACCTCCTAAGGGACCTAG AG-3' ${ }^{\prime}$, rev $5^{\prime}$-CTCTAGGTCCCTTAGGAGGTC-3'; and for hGH K166R, fwd 5'-CAGATCTT CAGGCAGACCTAC-3' ${ }^{\prime}$, rev $5^{\prime}$-GTAGGTCTGCCTGAAGATCTG-3'. Three mutant plasmid DNAs from which one lysine residue was replaced by arginine $(K->R)$ were produced using pCS4-Flag-hGH as a template (Supplementary Table S2).

\subsection{Cell Lines}

NIH3T3 (mouse embryo fibroblast cell line, ATCC CRL-1658, Manassas, VA, USA) and HEK 293T cell (human embryonic kidney cell line, ATCC CRL-11268) were grown in Dulbecco's modified Eagle's medium (DMEM, GIBCO BRL, Rockville, MD, USA) supplemented with $10 \%$ fetal bovine serum (FBS, GIBCO BRL) and $1 \%$ penicillin and streptomycin (GIBCO BRL).

\subsection{Ubiquitination Analysis in Cells}

The HEK 293T cells were counted, seeded using SOL COUNT (SOL Inc., Seoul, Korea) into $1 \times 10^{7}$ cells in 100-mm culture plate, and transfected with the plasmid encoding pCS4-Flag-hGH and pMT123-HA-ubiquitin [43]. To check the ubiquitination level of hGH and its mutants, the HEK 293T cells were co-transfected with $1 \mu \mathrm{g}$ of pMT123-HA-ubiquitin DNA and $4 \mu \mathrm{g}$ of pCS4-Flag-hGH, pCS4-Flag-hGH (K67R), pCS4-Flag-hGH (K141R) and pCS4-Flag-hGH (K166R). At $24 \mathrm{~h}$ after the transfection, the cells were treated with MG132 (Sigma-Aldrich, M7449, Darmstadt, Germany) (proteasome inhibitor, $5 \mu \mathrm{g} / \mathrm{mL}$ ) for $6 \mathrm{~h}$, after which immunoprecipitation analysis was carried out.

The sample obtained for the immunoprecipitation was dissolved in a buffer solution (1\% Triton X, $150 \mathrm{mM} \mathrm{NaCl}, 50 \mathrm{mM}$ Tris- $\mathrm{HCl}$ (pH 8.0), and $1 \mathrm{mM} \mathrm{PMSF}$ ) and was then mixed with anti-Flag (Sigma-Aldrich, F3165). Subsequently, the mixture was incubated at $4{ }^{\circ} \mathrm{C}$ overnight. The immunoprecipitant was separated following the reaction with $\mathrm{A} / \mathrm{G}$ bead at $4{ }^{\circ} \mathrm{C}$ for $2 \mathrm{~h}$. Then, the separated immunoprecipitant was washed twice with buffering solution. The protein sample was separated by SDS-PAGE, after mixing with $2 \times$ SDS buffer and heating at $100{ }^{\circ} \mathrm{C}$ for $7 \mathrm{~min}$. The separated protein was transferred to the polyvinylidene difluoride membrane (PVDF, Millipore, Darmstadt, Germany), and an anti-HA antibody (sc-7392, Santa Cruz Biotechnology, Santa Cruz, CA, USA) was used for Western blotting. Blots were detected using ECL reagent solution (Western blot detection kit, Ab Frontier, Seoul, Korea).

\subsection{Analysis of Half-Life Using Protein Synthesis Inhibitor}

The HEK 293T cells were counted, seeded using SOL COUNT (SOL Inc.) into $1 \times 10^{7}$ cells in 100-mm culture plate, and transfected with $2 \mu \mathrm{g}$ of pCS4-Flag- hGH, pCS4-Flag- hGH (K67R), pCS4-Flag- hGH (K141R) and pCS4-Flag- hGH (K166R), respectively. At $24 \mathrm{~h}$ after the transfection, the cells were seeded into $60-\mathrm{mm}$ culture plates, and treated with the protein synthesis inhibitor, cycloheximide (CHX) (Sigma-Aldrich) $(100 \mu \mathrm{g} / \mathrm{mL})$, and then the half-life of each protein was detected at 1, 2, 4 and $8 \mathrm{~h}$ after the treatment of the protein synthesis inhibitor. Furthermore, MG132 (Sigma-Aldrich) $(5 \mu \mathrm{g} / \mathrm{mL})$ was independently treated for $0,1,2$ and $4 \mathrm{~h}$. For Western blot analysis to detect hGH proteins, an anti-Flag (F3165, Sigma-Aldrich) antibody was used. 


\subsection{Purification of rhGH and AUT-rhGH}

For untagged hGH, PCR was performed from pCS4-Flag-hGH, and pCS4-Flag-AUThGH using fwd 5'-GCGCCATGGCGATGTTCCCAACCATTCCCTTAT-3' and rev 5'-GCGC TCGAGCTAGAAGCCACAGCTGCCCTC-3', respectively. For cloning pET-28a (Novagen, Madison, WI, USA), Nco I and Xho I restriction enzyme sites were used. The nucleotide sequences of inserts were verified by direct sequencing (3730xl DNA Analyzers, Applied Biosystems, Waltham, MA, USA).

Subsequently, pET28a-hGH and pET28a-AUT-hGH were transformed into E. coli BL21 (DE3) cells for protein expression. A $25 \mathrm{~mL}$ aliquot of an overnight culture was seeded into $2 \mathrm{~L}$ of fresh $\mathrm{LB}$ medium containing $50 \mathrm{mg} / \mathrm{mL}$ kanamycin and grown at $37{ }^{\circ} \mathrm{C}$ to reach an $\mathrm{OD}_{600}$ absorbance of 0.6-0.8. Subsequently, protein expression was induced with $1 \mathrm{mM}$ IPTG, and the cells were further cultured for another $16 \mathrm{~h}$ at $20^{\circ} \mathrm{C}$. After culture, the cells were harvested by centrifugation at 3,000 rpm, and cell pellets were suspended in lysis buffer (50 mM Tris- $\mathrm{HCl}$ (pH8.0), 10\% glycerol) containing protease inhibitor cocktail (Roche, Barcelona, Spain) and sonication was applied at $4{ }^{\circ} \mathrm{C}$. Subsequently, the lysate was centrifuged at 13,000 rpm, for $30 \mathrm{~min}$ at $4{ }^{\circ} \mathrm{C}$, and soluble supernatants were obtained. For purification, soluble supernatants were loaded onto a 20 mL Hiprep DEAE FF 16/10 column (GE Healthcare, Chicago, IL, USA) and purified by anion exchange and gel filtration chromatography using AKTA Starter (GE Healthcare). All purification procedures were performed at $4{ }^{\circ} \mathrm{C}$. Protein concentration was determined by the Bradford and bicinchoninic acid (BCA, Bio-Rad, Hercules, CA, USA) assays using bovine serum albumin (BSA) as a standard [44]. Protein purity was initially monitored by SDS-PAGE and silver staining.

\subsection{Comparison of Structure of $h \mathrm{GH}$ and AUT- $h \mathrm{GH}$}

To compare the structure of hGH and AUT-hGH, an hGH pdb file was obtained from the RCSB protein data bank site (https: / / www.rcsb.org, accessed on 29 November 2018). The AUT-hGH pdb file was saved using a mutagenesis algorithm of the PyMOL program (The PyMOL Molecular Graphics System, Version 2.0 Schrödinger, LLC). The structure of AUT-hGH was compared with that of hGH using the Wincoot program (ver. 0.9.4.1) [32].

\subsection{Signal Transduction by $h G H$ and Its Mutant in Cells}

To examine the signal transduction by hGH, AUT-hGH, commercial hGH (Saizen, Merck Serono, Darmstadt, Germany), NIH3T3 cells were counted, seeded using SOL COUNT (SOL Inc.) into $1 \times 10^{6}$ cells in $60-\mathrm{mm}$ culture plate, and starved in DMEM supplemented with $0.5 \%$ FBS for a day. The hGHs were then treated with $100 \mathrm{ng} / \mathrm{mL}$ for 2 days. After 2 days, Western blotting was performed to analyze the signal transduction in cells. Anti-STAT3 (sc-482, Santa Cruz), anti-phospho-STAT3 (9131S, Cell Signaling Technology, Danvers, MA, USA), anti-AKT (sc-8312, Santa Cruz), anti-phospho-AKT (9271S, Cell Signaling Technology), anti-ERK1/2 (LF-MA0134, Ab frontier), anti-phosphoERK1/2 (LF-PA0090, Ab frontier), and anti- $\beta$-actin (sc-47778, Santa Cruz) were used for Western blot analysis.

\subsection{Pharmacokinetic Study of AUT-hGH}

\subsubsection{Animals and Treatment}

The 8-week-old male SD rats were purchased from Orient Bio Co. Ltd. (Senongnamsi, Korea) and used after monitoring for a week. The experimental procedures were performed following the Biotoxtech (Cheongju, Korea) guidelines (experiment number B18854). Two to three rats were housed in every cage during monitoring and one rat per cage $(260 \mathrm{~W} \times 350 \mathrm{D} \times 210 \mathrm{H}(\mathrm{mm}))$ during the experiment. The animal groups consisted of negative control, hGH, AUT-hGH, and Saizen (as a comparative substance), and all substances were single subcutaneously administered, respectively. A single dose of hGH, AUT-hGH, and Saizen was set to $720 \mu \mathrm{g} / \mathrm{kg}$. The normal and negative controls received injectable water, as an excipient. The volume of the solution was set at $1 \mathrm{~mL} / \mathrm{kg}$, and the 
volume of the solution was calculated based on the weight measured close to the day of administration.

\subsubsection{Blood Sampling}

Blood samples were collected at $0,1,2,4,8,12,16,24,30$ and $48 \mathrm{~h}$ after administration. About $0.5 \mathrm{~mL}$ of blood was collected from the jugular vein using a disposable syringe (1 mL, 25 G, Doowon Meditec Corp., Yongin, Korea) treated with heparin (Lot No.: 14030, Choongwae Pharma Corp., Seoul, Korea, $100 \mathrm{IU} / \mathrm{mL}$ ) and placed in a microtube in a refrigerated state. To separate plasma, blood was separated into two microtubes $(100 \mu \mathrm{L}$ per sampling point) and rapidly centrifuged (12,000 rpm, $3 \mathrm{~min}, 4^{\circ} \mathrm{C}$, Micro 17TR, Hanil Science Industrial, Gimpo, Korea), and kept cooling in dry ice. The separated plasma was kept in an ultra-low temperature freezer $\left(-80-60{ }^{\circ} \mathrm{C}\right.$, DFU-657CL, Operon, Gimpo, Korea) before analysis.

\subsubsection{ELISA for the Detection of hGH in Plasma}

ELISA for hGH and AUT-hGH was performed using a Quantikine ELISA kit of hGH (RnD System, Minneapolis, MN, USA). The experiment was performed according to the provided instructions. The values represent the means \pm SEM of the three independent experiments.

\subsubsection{Analysis for the Half-Life of AUT-hGH}

Half-life analysis was performed as shown at the sites https://asan.shinyapps.io/ pkrshiny/ (accessed on 28 May 2021) and https:/ / www.aatbio.com/tools/ed50-calculator (accessed on 6 December 2018).

\subsection{Ubiquitination of hGH in Blood}

\subsubsection{Plasma Preparation and Pull-Down Assay Using Ni-NTA Beads}

hGH-His was constructed by removing the stop codon from the aforementioned pET-28a-hGH using site-directed mutagenesis for PCR. The protein was purified by the same purification method as described above. In addition, then, to investigate whether $\mathrm{hGH}$ is ubiquitinated in the blood stream, $300 \mu \mathrm{L}$ mouse whole blood was cleared for $1 \mathrm{~h}$ at $4{ }^{\circ} \mathrm{C}$ using $300 \mu \mathrm{L}$ protein A/G Agarose (sc-2003, Santa Cruz), then centrifuged twice at $3000 \mathrm{rpm}$ for $1 \mathrm{~min}$ to obtain supernatants. An amount of $100 \mathrm{ng}$ of purified hGH-His was incubated for $1 \mathrm{~h}$ at $37^{\circ} \mathrm{C}$ with MG132 (Sigma-Aldrich) $(5 \mu \mathrm{g} / \mathrm{mL}$ ) in $1.3 \mathrm{~mL}$ mouse whole blood and pull-down assay was performed using $30 \mu \mathrm{L}$ Ni-NTA beads (Qiagen, Hilden, Germany). Then, the precipitant for hGH-His was washed five times with phosphate-buffered saline (PBS, Biosesang, Seongnam-si, Korea).

\subsubsection{SDS-PAGE Separation}

Precipitant hGH-His was mixed with $5 \times$ SDS loading buffer and boiled for $10 \mathrm{~min}$ at $80^{\circ} \mathrm{C}$ on a heat block. After centrifugation, each protein sample was applied on $12 \%$ SDS-PAGE. After visualization using Coomassie brilliant blue (Bio-Rad), the gel from each lane was cut into eight fractions and chopped into small pieces $\mathrm{f}$ or in-gel digestion.

\subsubsection{Enzymatic In-Gel Digestion}

For the digestion, the gel pieces were washed with distilled water three times to remove SDS and dehydrated using $100 \%$ acetonitrile (ACN). Protein reduction was performed using $10 \mathrm{mM}$ dithiothreitol in $50 \mathrm{mM} \mathrm{NH}_{4} \mathrm{HCO}_{3}$ for $45 \mathrm{~min}$ at $56^{\circ} \mathrm{C}$. After washing with $100 \% \mathrm{ACN}$, alkylation of cysteines was done with $55 \mathrm{mM}$ iodoacetamide in $50 \mathrm{mM}$ $\mathrm{NH}_{4} \mathrm{HCO}_{3}$ for $30 \mathrm{~min}$ in the dark. Finally, each dehydrated gel piece was treated with $12.5 \mathrm{ng} / \mu \mathrm{L}$ sequencing grade modified trypsin (Promega, Madison, WI, USA) in $50 \mathrm{mM}$ $\mathrm{NH}_{4} \mathrm{HCO}_{3}$ buffer ( $\mathrm{pH} 7.8$ ) at $37^{\circ} \mathrm{C}$ for overnight. Following digestion, tryptic peptides were extracted with $5 \%$ formic acid in 50\% ACN solution at room temperature for $20 \mathrm{~min}$. The supernatants were collected and dried with SpeedVac. Before MS analysis, the sam- 
ples suspended in $0.1 \%$ formic acid were purified and concentrated using C18 ZipTips (Millipore, Burlington, MA, USA).

\subsubsection{Nano-LC-ESI-MS/MS Analysis}

Peptide separation was performed using Dionex UltiMate 3000 RSLCnano system (Thermo-Fisher Scientific, Waltham, MA, USA). Tryptic peptides from bead column were reconstituted using $0.1 \%$ formic acid and separated on a 50-cm Easy-Spray column with a 75- $\mu \mathrm{m}$ inner diameter packed with $2 \mu \mathrm{m} \mathrm{C18} \mathrm{resin} \mathrm{(Thermo-Fisher} \mathrm{Scientific)} \mathrm{over} 120 \mathrm{~min}$ ( $300 \mathrm{~nL} / \mathrm{min}$ ) using a 0 to $45 \% \mathrm{ACN}$ gradient in $0.1 \%$ formic acid at $50{ }^{\circ} \mathrm{C}$. The $\mathrm{LC}$ was coupled to a $\mathrm{Q}$ Exactive Plus BioPharm mass spectrometer with a nano-ESI source (ThermoFisher Scientific). Mass spectra were acquired in a data-dependent mode with an automatic switch between a full scan and five data-dependent MS/MS scans. The target value for the full scan MS spectra was 3,000,000 with a maximum injection time of $120 \mathrm{~ms}$ and a resolution of 70,000 at $\mathrm{m} / \mathrm{z} 400$. The ion target value for MS/MS was set to $1,000,000$ with a maximum injection time of $120 \mathrm{~ms}$ and a resolution of $17500 \mathrm{at} \mathrm{m} / \mathrm{z} 400$. Dynamic exclusion of repeated peptides was applied for $20 \mathrm{~s}$.

\subsubsection{Database Searching}

The resulting raw files were processed using Proteome Discoverer (version 2.3, ThermoFisher Scientific) for identification with the database of Homo sapiens (organism ID: 9606, 71567 entries, UniProt). The search parameters were set as default including cysteine carbamidomethylation as a fixed modification, N-terminal acetylation, methionine oxidation phospho-serine, -threonine and -tyrosine as variable modifications and di-glycine modification at lysine residue with two miscleavages. Peptide identification was based on a search with an initial mass deviation of the precursor ion of up to $10 \mathrm{ppm}$, and the allowed fragment mass deviation was set to $20 \mathrm{ppm}$.

\subsubsection{Polyubiquitination of hGH in the Blood Stream}

hGH-His was incubated with and without MG132 (Sigma-Aldrich) $(5 \mu \mathrm{g} / \mathrm{mL})$. As previously explained, pull-down assay was performed. In addition, then, Western blotting was performed using an anti-ubiquitin antibody (sc-8017, Santa Cruz) to examine the polyubiquitinated hGH in the blood stream.

\subsection{Efficacy Study of AUT-hGH}

\subsubsection{Animals and Treatment}

Rats with their pituitary gland removed at 4 weeks of age and normal rats were purchased from Orient Bio Inc. and used after monitoring for a week. The experimental procedures were performed following the guideline of Biotoxtech Inc. (experiment number B17622). The animal groups consisted of the negative and positive controls, $\mathrm{hGH}$, and AUT-hGH. All substances were administered on a daily basis, and in intervals of 3 days and 7 days, repeatedly. The single dose of hGH and AUT-hGH was set to $0.44 \mathrm{IU} / \mathrm{kg}$.

\subsubsection{Measurement of Length for Growth Plate}

Before tibial extraction, tetracycline hydrochloride (Lot No.: SLBQ2368V, SigmaAldrich) was administered intraperitoneally at $20 \mathrm{mg} / \mathrm{kg}$ for $72 \mathrm{~h}$. It was prepared and used in a physiological saline injection solution (Lot No.: GAA6023, JW Pharmaceutical Co., Ltd., Korea) at $4 \mathrm{mg} / \mathrm{mL}$. Then the collected tibia was fixed in $4 \%$ paraformaldehyde (Lot No.: \#STBG9973, Sigma-Aldrich) for $48 \mathrm{~h}$ and then 10\% ethylene diamine tetra acetic acid (Lot No.: E0008RG1, Daejung Chemicals \& Metals Co., Ltd., Korea) solution and demineralized for $24 \mathrm{~h}$. The tibia after demineralization was dehydrated for $24 \mathrm{~h}$ by putting it in 30\% sucrose (Lot No.: \#SLBR5401V, Sigma-Aldrich) solution. Next, the tibia was cut to a thickness of $40 \mu \mathrm{m}$ in the longitudinal direction (longitudinally) using a cryosection machine (CM3050S, Leica, Germany) and attached to the slide. The prepared frozen section slide was sealed with Fluormount, observed with a fluorescence microscope (Observer 
Z1, Carl Zeiss, Germany) and photographed with a tissue (Axiovision V.4.6, Carl Zeiss) to measure the length between the bands produced by tetracycline in the growth plate.

Supplementary Materials: Supplementary materials can be found at https://www.mdpi.com/ article/10.3390/ijms22126268/s1.

Author Contributions: M.-S.K. performed the overall experiment and wrote the manuscript. K.K. performed MS analysis, interpreted the data, and wrote the manuscript. S.K.O. performed cloning of hGH-His and ELISA. G.L. purified all hGH proteins. J.-H.P., J.-O.K., and L.L. performed initiated cloning of pCS4-flag-hGH and their mutants. K.-H.B. formulated the hypothesis and contributed relevantly to the manuscript. All authors have read and agreed to the published version of the manuscript.

Funding: This research received no external funding.

Institutional Review Board Statement: This study was conducted according to the Animal Protection Act. (Enactment 31 May 1991 Act No. 4379, and Minor Amendment Act No. 15502 of 20 March 2018), and was approved by Animal Experimentation Ethics Committee in Biotoxtech (approval number: 170679 and 180713).

Informed Consent Statement: Not applicable.

Acknowledgments: We would like to thank Sung-Ryul Bae and Kwan-Hee Park at UbiProtein Corp. for funding and team members at Biotextech Inc. for rat experiments, technical assistance, comments on the manuscript, and technical assistance.

Conflicts of Interest: The authors declare no conflict of interest.

\section{Abbreviations}

$\begin{array}{ll}\text { AUT } & \text { Anti-ubiquitination technology } \\ \text { CHX } & \text { Cycloheximide } \\ \text { DEAE } & \text { Diethylaminoethyl cellulose } \\ \text { DMEM } & \text { Dulbecco's modified Eagle's medium } \\ \text { E1 } & \text { Ubiquitin-activating } \\ \text { E2E3 } & \text { Ubiquitin-conjugating Ubiquitin-ligase } \\ \text { ELISA } & \text { Enzyme-linked immunosorbent assay } \\ \text { FBS } & \text { Fetal bovine serum } \\ \text { hGHIPTG } & \text { Human growth hormoneIsopropyl-b-D-thiogalactopyranoside } \\ \text { Nano-LC-ESI-MS/MS } & \text { Nano liquid chromatography-tandem mass spectrometry } \\ \text { PMSFSDS-PAGE } & \text { Phenylmethanesulfonyl fluorideSodium dodecyl sulfate- } \\ & \text { polyacrylamide gel electrophoresis }\end{array}$

\section{References}

1. Lan, H.; Nie, Z.; Liu, Y.; Lv, Z.; Liu, Y.; Quan, Y.; Chen, J.; Zhen, Q.; Chen, Q.; Wang, D.; et al. In Vivo Bioassay of Recombinant Human Growth Hormone Synthesized in B. Mori Pupae. J. Biomed. Biotechnol. 2010, 2010, 306462. [CrossRef]

2. Le Roith, D.; Bondy, C.; Yakar, S.; Liu, J.-L.; Butler, A. The Somatomedin Hypothesis: 2001. Endocr. Rev. 2001, 22, 53-74. [CrossRef]

3. Kang, J.; Wu, F.; Cai, Y.; Xu, M.; He, M.; Yuan, W. Development of Recombinant Human Growth Hormone (rhGH) sustainedrelease microspheres by a low temperature aqueous phase/aqueous phase emulsion method. Eur. J. Pharm. Sci. 2014, 62, 141-147. [CrossRef]

4. Ghasemi, R.; Abdollahi, M.; Zadeh, E.E.; Khodabakhshi, K.; Badeli, A.; Bagheri, H.; Hosseinkhani, S. mPEG-PLA and PLAPEG-PLA nanoparticles as new carriers for delivery of recombinant human Growth Hormone (rhGH). Sci. Rep. 2018, 8, 9854. [CrossRef] [PubMed]

5. Govardhan, C.; Khalaf, N.; Jung, C.W.; Simeone, B.; Higbie, A.; Qu, S.; Chemmalil, L.; Pechenov, S.; Basu, S.K.; Margolin, A.L. Novel Long-Acting Crystal Formulation of Human Growth Hormone. Pharm. Res. 2005, 22, 1461-1470. [CrossRef] [PubMed]

6. Kwak, H.; Shim, W.; Choi, M.; Son, M.; Kim, Y.; Yang, H.; Kim, T.; Lee, G.; Kim, B.; Kang, S.; et al. Development of a sustained-release recombinant human growth hormone formulation. J. Control. Release 2009, 137, 160-165. [CrossRef] [PubMed]

7. Jordan, F.; Naylor, A.; Kelly, C.; Howdle, S.; Lewis, A.; Illum, L. Sustained release hGH microsphere formulation produced by a novel supercritical fluid technology: In vivo studies. J. Control. Release 2010, 141, 153-160. [CrossRef] [PubMed] 
8. Seo, B.-B.; Park, M.-R.; Chun, C.; Lee, J.-Y.; Song, S.-C. The biological efficiency and bioavailability of human growth hormone delivered using injectable, ionic, thermosensitive poly(organophosphazene)-polyethylenimine conjugate hydrogels. Biomaterials 2011, 32, 8271-8280. [CrossRef]

9. Park, M.-R.; Chun, C.; Ahn, S.-W.; Ki, M.-H.; Cho, C.-S.; Song, S.-C. Sustained delivery of human growth hormone using a polyelectrolyte complex-loaded thermosensitive polyphosphazene hydrogel. J. Control. Release 2010, 147, 359-367. [CrossRef]

10. Park, M.-R.; Chun, C.; Ahn, S.-W.; Ki, M.-H.; Cho, C.-S.; Song, S.-C. Cationic and thermosensitive protamine conjugated gels for enhancing sustained human growth hormone delivery. Biomaterials 2010, 31, 1349-1359. [CrossRef]

11. García, J.T.; Dorta, M.J.; Munguía, O.; Llabrés, M.; Fariña, J.B. Biodegradable laminar implants for sustained release of recombinant human growth hormone. Biomaterials 2002, 23, 4759-4764. [CrossRef]

12. Santoveña, A.; Garcia, J.; Oliva, A.; Llabres, M.; Fariña, J. A mathematical model for interpreting in vitro rhGH release from laminar implants. Int. J. Pharm. 2006, 309, 38-43. [CrossRef] [PubMed]

13. Yuen, K.C.; Miller, B.S.; Biller, B.M. The current state of long-acting growth hormone preparations for growth hormone therapy. Curr. Opin. Endocrinol. Diabetes Obes. 2018, 25, 267-273. [CrossRef] [PubMed]

14. Kim, E.-S.; Jang, D.S.; Yang, S.Y.; Lee, M.N.; Jin, K.S.; Cha, H.J.; Kim, J.K.; Sung, Y.C.; Choi, K.Y. Controlled release of human growth hormone fused with a human hybrid Fc fragment through a nanoporous polymer membrane. Nanoscale 2013, 5, 4262. [CrossRef] [PubMed]

15. Ku, C.R.; Brue, T.; Schilbach, K.; Ignatenko, S.; Magony, S.; Chung, Y.-S.; Kim, B.-J.; Hur, K.Y.; Kang, H.-C.; Kim, J.H.; et al. Long-acting FC-fusion rhGH (GX-H9) shows potential for up to twice-monthly administration in GH-deficient adults. Eur. J. Endocrinol. 2018, 179, 169-179. [CrossRef] [PubMed]

16. Fares, F.; Guy, R.; Bar-Ilan, A.; Felikman, Y.; Fima, E. Designing a Long-Acting Human Growth Hormone (hGH) by Fusing the Carboxyl-Terminal Peptide of Human Chorionic Gonadotropin Beta-Subunit to the Coding Sequence of hGH. Endocrinology 2010, 151, 4410-4417. [CrossRef] [PubMed]

17. Zelinska, N.; Iotova, V.; Skorodok, J.; Malievsky, O.; Peterkova, V.; Samsonova, L.; Rosenfeld, R.G.; Zadik, Z.; Jaron-Mendelson, M.; Koren, R.; et al. Long-Acting CTP-Modified hGH (MOD-4023): Results of a Safety and Dose-Finding Study in GHD Children. J. Clin. Endocrinol. Metab. 2017, 102, 1578-1587. [CrossRef]

18. Rasmussen, M.H.; Olsen, M.W.B.; Alifrangis, L.; Klim, S.; Suntum, M. A Reversible Albumin-Binding Growth Hormone Derivative is Well Tolerated and Possesses a Potential Once-Weekly Treatment Profile. J. Clin. Endocrinol. Metab. 2014, 99, E1819-E1829. [CrossRef] [PubMed]

19. Johannsson, G.; Feldt-Rasmussen, U.; Håkonsson, I.H.; Biering, H.; Rodien, P.; Tahara, S.; A Toogood, A.; Rasmussen, M.H.; Karges, W.; Mann, A.; et al. Safety and convenience of once-weekly somapacitan in adult GH deficiency: A 26-week randomized, controlled trial. Eur. J. Endocrinol. 2018, 178, 491-499. [CrossRef]

20. Juul, R.V.; Rasmussen, M.H.; Agersø, H.; Overgaard, R.V. Pharmacokinetics and Pharmacodynamics of Once-Weekly Somapacitan in Children and Adults: Supporting Dosing Rationales with a Model-Based Analysis of Three Phase I Trials. Clin. Pharmacokinet. 2018, 58, 63-75. [CrossRef]

21. Luo, X.-P.; Hou, L.; Chen, Z.-H.; Liu, D.; Cheng, Y.-G. Comparative pharmacokinetics and pharmacodynamics of a PEGylated recombinant human growth hormone and daily recombinant human growth hormone in growth hormone-deficient children. Drug Des. Dev. Ther. 2015, 10, 13-21. [CrossRef] [PubMed]

22. Luo, X.; Hou, L.; Liang, L.; Dong, G.; Shen, S.; Zhao, Z.; Gong, C.X.; Li, Y.; Du, M.-L.; Su, Z.; et al. Long-acting PEGylated recombinant human growth hormone (Jintrolong) for children with growth hormone deficiency: Phase II and phase III multicenter, randomized studies. Eur. J. Endocrinol. 2017, 177, 195-205. [CrossRef]

23. Lim, K.-H.; Joo, J.-Y.; Baek, K.-H. The potential roles of deubiquitinating enzymes in brain diseases. Ageing Res. Rev. 2020, 61, 101088. [CrossRef]

24. Suresh, B.; Lee, J.; Kim, H.; Ramakrishna, S. Regulation of pluripotency and differentiation by deubiquitinating enzymes. Cell Death Differ. 2016, 23, 1257-1264. [CrossRef]

25. Sujashvili, R. Advantages of Extracellular Ubiquitin in Modulation of Immune Responses. Mediat. Inflamm. 2016, $2016,4190390$. [CrossRef]

26. Takada, K.; Nasu, H.; Hibi, N.; Tsukada, Y.; Shibasaki, T.; Fujise, K.; Fujimoro, M.; Sawada, H.; Yokosawa, H.; Ohkawa, K. Serum Concentrations of Free Ubiquitin and Multiubiquitin Chains. Clin. Chem. 1997, 43, 1188-1195. [CrossRef] [PubMed]

27. Majetschak, M. Extracellular ubiquitin: Immune modulator and endogenous opponent of damage-associated molecular pattern molecules. J. Leukoc. Biol. 2010, 89, 205-219. [CrossRef] [PubMed]

28. Kim, M.-J.; Park, H.S.; Seo, K.H.; Yang, H.-J.; Kim, S.-K.; Choi, J.-H. Complete Solubilization and Purification of Recombinant Human Growth Hormone Produced in Escherichia coli. PLoS ONE 2013, 8, e56168. [CrossRef]

29. Francis, D.M.; Page, R. Strategies to Optimize Protein Expression in E. coli. Curr. Protoc. Protein Sci. 2010, 61, 5.24.1-5.24.29. [CrossRef] [PubMed]

30. Baneyx, F.; Mujacic, M. Recombinant protein folding and misfolding in Escherichia coli. Nat. Biotechnol. 2004, 22, 1399-1408. [CrossRef]

31. Jewett, A.I.; Huang, C.C.; Ferrin, T.E. MINRMS: An efficient algorithm for determining protein structure similarity using root-mean-squared-distance. Bioinformatics 2003, 19, 625-634. [CrossRef] 
32. Emsley, P.; Lohkamp, B.; Scott, W.G.; Cowtan, K.D. Features and development ofCoot. Acta Crystallogr. Sect. D Biol. Crystallogr. 2010, 66, 486-501. [CrossRef] [PubMed]

33. Herrington, J.; Smit, L.S.; Schwartz, J.; Carter-Su, C. The role of STAT proteins in growth hormone signaling. Oncogene 2000, 19, 2585-2597. [CrossRef] [PubMed]

34. Carter-Su, C.; Schwartz, J.; Argetsinger, L.S. Growth hormone signaling pathways. Growth Horm. IGF Res. 2016, 28 , 11-15. [CrossRef] [PubMed]

35. De Groot, M.C.H.; van Zwieten-Boot, B.J.; van Grootheest, A.C. Severe Adverse Reactions after the Use of Sulphur Hexafluoride (SonoVue) as an Ultrasonographic Contrast Agent. Ned. Tijdschr. Geneeskd. 2004, 148, 1887-1888. [PubMed]

36. Pérez-Pérez, L.; García-Gavín, J.; Piñeiro, B.; Zulaica, A. Biologic-induced urticaria due to polysorbate 80: Usefulness of prick test. Br. J. Dermatol. 2011, 164, 1119-1120. [CrossRef] [PubMed]

37. Sundy, J.S.; Baraf, H.S.B.; Yood, R.A.; Edwards, N.L.; Gutierrez-Urena, S.R.; Treadwell, E.L.; Vázquez-Mellado, J.; White, W.B.; Lipsky, P.E.; Horowitz, Z.; et al. Efficacy and Tolerability of Pegloticase for the Treatment of Chronic Gout in Patients Refractory to Conventional Treatment. JAMA 2011, 306, 711-720. [CrossRef] [PubMed]

38. Bendele, A.; Seely, J.; Richey, C.; Sennello, G.; Shopp, G. Short Communication: Renal Tubular Vacuolation in Animals Treated with Polyethylene-Glycol-Conjugated Proteins. Toxicol. Sci. 1998, 42, 152-157. [CrossRef]

39. Bukowski, R.; Ernstoff, M.S.; Gore, M.E.; Nemunaitis, J.J.; Amato, R.; Gupta, S.K.; Tendler, C.L. Pegylated Interferon Alfa-2b Treatment for Patients with Solid Tumors: A Phase I/II Study. J. Clin. Oncol. 2002, 20, 3841-3949. [CrossRef]

40. Gregoriadis, G.; Jain, S.; Papaioannou, I.; Laing, P. Improving the therapeutic efficacy of peptides and proteins: A role for polysialic acids. Int. J. Pharm. 2005, 300, 125-130. [CrossRef] [PubMed]

41. Caliceti, P. Pharmacokinetic and biodistribution properties of poly(ethylene glycol)-protein conjugates. Adv. Drug Deliv. Rev. 2003, 55, 1261-1277. [CrossRef]

42. Lim, K.-H.; Suresh, B.; Park, J.-H.; Kim, Y.-S.; Ramakrishna, S.; Baek, K.-H. Ubiquitin-specific protease 11 functions as a tumor suppressor by modulating Mgl-1 protein to regulate cancer cell growth. Oncotarget 2016, 7, 14441-14457. [CrossRef] [PubMed]

43. Baek, K.-H.; Kim, M.-S.; Kim, Y.-S.; Shin, J.-M.; Choi, H.-K. DUB-1A, a Novel Deubiquitinating Enzyme Subfamily Member, Is Polyubiquitinated and Cytokine-inducible in B-lymphocytes. J. Biol. Chem. 2004, 279, 2368-2376. [CrossRef] [PubMed]

44. Smith, P.; Krohn, R.; Hermanson, G.; Mallia, A.; Gartner, F.; Provenzano, M.; Fujimoto, E.; Goeke, N.; Olson, B.; Klenk, D. Measurement of protein using bicinchoninic acid. Anal. Biochem. 1985, 150, 76-85. [CrossRef] 